\title{
Antiviral treatment in COVID-19: which is the most promising? - a narrative review
}

\author{
Ambedkar Kumar Yadav", Siwan Wen", Xianghuai Xu, Li Yu \\ Department of Pulmonary and Critical Care Medicine, Tongji Hospital, Tongji University School of Medicine, Shanghai, China \\ Contributions: (I) Conception and design: AK Yadav, S Wen; (II) Administrative support: X Xu, L Yu; (III) Provision of study materials or patients: AK \\ Yadav, S Wen; (IV) Collection and assembly of data: AK Yadav, S Wen; (V) Data analysis and interpretation: All authors; (VI) Manuscript writing: All \\ authors; (VII) Final approval of manuscript: All authors. \\ \#These authors contributed equally to this work. \\ Correspondence to: Xianghuai Xu; Li Yu. Department of Pulmonary and Critical Care Medicine, Tongji Hospital, Tongji University School of \\ Medicine, 389 Xincun Road, Shanghai 200065, China. Email: 05849@tongji.edu.cn; yuli0219@sina.com.
}

\begin{abstract}
The whole world is battling through coronavirus disease 2019 (COVID-19) which is a fatal pandemic. In the early 2020, the World Health Organization (WHO) declared it as a global health emergency without definitive treatments and preventive approaches. In the absence of definitive therapeutic agents, this thorough review summarizes and outlines the potency and safety of all molecules and therapeutics which may have potential antiviral effects. A number of molecules and therapeutics licensed or being tested for some other conditions were found effective in different in vitro studies as well as in many small sample-sized clinical trials and independent case studies. However, in those clinical trials, there were some limitations which need to be overcome to find the most promising antiviral against severe acute respiratory syndrome coronavirus 2 (SARS-CoV-2). In conclusion, many of above-mentioned antivirals seems to have some therapeutic effects but none of them have been shown to have a strong evidence for their proper recommendation and approval in the treatment of COVID-19. Constantly evolving new evidences, exclusive adult data, language barrier, and type of study (observational, retrospective, small-sized clinical trials, or independent case series) resulted to the several limitations of this review. The need for multicentered, large sample-sized, randomized, placebo-controlled trials on COVID-19 patients to reach a proper conclusion on the most promising antiviral agent is warranted.
\end{abstract}

Keywords: Coronavirus disease 2019 (COVID-19); severe acute respiratory syndrome coronavirus 2 (SARS$\mathrm{CoV}-2)$; therapeutic agents; treatment; antiviral; coronavirus

Submitted Aug 31, 2020. Accepted for publication Dec 08, 2020.

doi: 10.21037/apm-20-1755

View this article at: http://dx.doi.org/10.21037/apm-20-1755

\section{Introduction}

Although coronavirus was uncovered for the first time in the 1960s, it hits the humankind with potential lethal afflictions from time to time (1). After severe acute respiratory syndrome (SARS) in 2003 (2) and Middle East Respiratory Syndrome (MERS) in 2012 (3), coronavirus disease 2019 (COVID-19) is the most recent coronavirus that afflicted mankind. Newly uncovered severe acute respiratory syndrome coronavirus 2 (SARS-CoV-2) was identified as a single stranded, enveloped, and positive sense RNA virus and added as the seventh representative of coronaviruses that attack humans (4). Among all seven known human coronavirus, SARS-CoV and MERS-CoV were previously recognized for their severe fatal infection, and SARS-CoV-2 is the recently recognized member leaving patients with very severe and fatal infections.

Its high transmissibility and infectivity made this disease a global health emergency which greatly threatened human health and the world economy (5). Due to its rapid spread in almost all continents of the world, it was declared as a pandemic by WHO on March $11^{\text {th }} 2020(6,7)$. According to the database 
of $\mathrm{WHO}$, at the beginning of November 2020, a total of 46 million patients have been diagnosed with COVID-19 and have spread to more than 200 countries along with 1.2 million deaths. The overall case fatality rate is about $2.57 \%$. The COVID-19 fatality rate varies significantly depending on the geographic region, lowest in Southeast Asia with $1.55 \%$ and highest in America with $3.10 \%$. Moreover, age is also found to cause an exponential variation in the fatality rate. The Korean Center for Disease Control and Prevention states that the COVID-19 fatality rate is significantly higher in the elderly (7.19\% in patients $70-79$ years of age and $20.46 \%$ in patients more than 80 years old) at the beginning of November 2020 (8). Earlier, in a previous analysis of 44672 COVID-19 cases in China, a similar pattern of higher mortality in the elderly was found $(8.0 \%$ in patients $70-79$ years of age and $14.8 \%$ in patients more than 80 years old) (9). The similar pattern of age-related mortality was also found in a report conducted by the Higher Institute of Health in Italy $(16.9 \%$ in patients $70-79$ years old and $24.4 \%$ in patients more than 80 years old) (10). Some studies also observed that multiple comorbidities tend to be associated with a higher case fatality rate. In a study in China, authors observed that confirmed COVID-19 patients with diabetes and hypertension as comorbidities demonstrated a $7.3 \%$ and $6 \%$ mortality rate, respectively (9). A similar result of comorbidity-related mortality was also found to be observed in another retrospective study where authors found a higher mortality $(21.1 \%$ vs. $7 \%)$ among those with diabetes than non-diabetic COVID-19 cases (11).

A pandemic always has an inherent challenge of conducting clinical trials urgently to decrease the fatality rate. Accordingly, various treatment modalities and molecules with a wide variety of mechanisms have been proposed for the treatment of COVID-19. Over 200 clinical trials are ongoing to test the potency and safety of antiviral agents against SARS-CoV-2. There are several previously approved as well as experimental antiviral drugs found to have potential therapeutic effects. The aim of this narrative review was to outline and summarize the clinical trials of the proposed and investigational drugs in treating COVID-19. We present the following article in accordance with the Narrative Review checklist (available at http://dx.doi.org/10.21037/apm-20-1755).

\section{Therapeutic interventions}

\section{Lopinavir/ritonavir}

The combination of lopinavir/ritonavir is a broadly discussed antiviral combo in many literatures and thought to have a promising potency in the treatment of COVID-19. Lopinavir is a protease inhibitor and known for decreasing the viral load by preventing viral replication in host cells $(12,13)$, while ritonavir is used with lopinavir to improve the efficacy and half-life of lopinavir by inhibiting cytochrome p450 (14). This combination therapy was previously registered for the treatment of HIV and MERS infection, which was found to be potent in inhibiting SARS-CoV (15).

Several clinical trials were conducted recently to test its efficacy and safety against COVID-19. Among these, one trial recruited 199 laboratory confirmed cases of COVID-19. This study showed that the duration of clinical improvement between the treatment group and the standard group was only one day with a similar mortality and viral clearance rate. The study also showed that there was no obvious treatment benefit of lopinavir/ritonavir combination against the SARS-CoV-2 infection (16). A similar result regarding virus clearance duration was indicated in another retrospective study (17). On the contrary, a small sample-sized $(n=47)$ retrospective study revealed a faster clinical improvement and shorter duration of virus clearance (18). Apart from these studies, some published case reports found lopinavir/ritonavir therapy beneficial in the clinical improvement along with shortening the duration of viral shedding $(19,20)$, but another descriptive case series showed no definite clinical benefit of using lopinavir/ritonavir as treatment (21). These studies showed an inconclusive result for the potency of lopinavir/ ritonavir in the treatment of COVID-19; however, due to some limitations such as a small sample size and lack of randomization, its effect in the treatment of COVID-19 needs further exploration (Table 1).

\section{Arbidol}

Arbidol \{ethyl-6-bromo-4-[(dimethylamino)methyl]-5 -hydroxy-1-methyl-2-[(phenylthio)methyl]-indole-3carboxylate hydrochloride monohydrate is a small indole derivative licensed in China and Russia as a prophylactic and therapeutic agent for the treatment of influenza A and B infections along with other respiratory viral infections (22). Arbidol exerts its antiviral effect by inhibiting the fusion of viral envelope with host cell membrane through the inhibition of endocytosis, thus preventing the entry of virus into host cells $(23,24)$. Due to its broad-spectrum antiviral activities, arbidol was found to have some potency in the treatment of COVID-19 through some small sample-sized clinical studies. 
Table 1 Clinical trials of lopinavir/ritonavir

\begin{tabular}{|c|c|c|c|c|c|}
\hline Authors & Year & Country & Study type & No. of participants & Findings \\
\hline Zhou et al. & 2020 & China & $\begin{array}{l}\text { Retrospective } \\
\text { cohort study }\end{array}$ & $\begin{array}{l}\text { Total }=191 ; \text { lopinavir/ } \\
\text { ritonavir group }=41\end{array}$ & $\begin{array}{l}\text { For overall survivors' median duration of virus sheading } \\
\text { was } 20 \text { days (IQR, 17-24) but it was } 22 \text { days (IQR, 18-24) } \\
\text { in survivors of lopinavir/ritonavir group }\end{array}$ \\
\hline Ye et al. & 2020 & China & $\begin{array}{l}\text { Retrospective } \\
\text { cohort study }\end{array}$ & $\begin{array}{l}\text { Total }=47 ; \text { lopinavir } / \\
\text { ritonavir test group }=42 \\
\text { control }=5\end{array}$ & $\begin{array}{l}\text { Body temperature of patient decrease faster in test group } \\
\text { but there was no statistical difference }(P>0.05) \\
\text { When number of days for temperature normalization } \\
\text { compared, patient in test group had shorter time than } \\
\text { control group, i.e., } 4.9 \pm 1.94 \text { vs. } 7.3 \pm 1.53 \text { days } \\
\text { Test group had shorter period of time for virus clearance } \\
\text { than control group, i.e., } 7.8 \pm 3.09 \text { vs. } 12.0 \pm 0.82\end{array}$ \\
\hline Lim et al. & 2020 & Korea & Case report & Total =1 & $\begin{array}{l}\text { Lopinavir/ritonavir related to reduction of viral load and } \\
\text { improvement of clinical symptoms }\end{array}$ \\
\hline Tang et al. & 2020 & China & Case report & Total $=1$ & $\begin{array}{l}\text { Negative conversion of SARS-COV-2 achieved only in } \\
8 \text { days of treatment with lopinavir/ritonavir with clinical } \\
\text { improvement }\end{array}$ \\
\hline Young et al. & 2020 & Singapore & $\begin{array}{l}\text { Descriptive case } \\
\text { series }\end{array}$ & $\begin{array}{l}\text { eTotal }=18 ; \text { lopinavir/ } \\
\text { ritonavir treatment } \\
\text { group }=5\end{array}$ & $\begin{array}{l}\text { Decline in viral load was similar between those treated and } \\
\text { not treated with lopinavir/ritonavir group }\end{array}$ \\
\hline
\end{tabular}

HR, hazard ratio; CI, confidence interval; IQR, interquartile range; SARS-COV-2, severe acute respiratory syndrome coronavirus 2.

Li et al. found little benefit of arbidol therapy in the rate and duration of negative conversion of SARS-CoV-2 nucleic acid along with the rate of clinical improvement and chest imaging over lopinavir/ritonavir therapy and standard supportive therapy (25). Unlike this study, a retrospective study found that arbidol therapy could improve symptoms, chest imaging, virus clearance, and hospital discharge rate as well as mortality rate among COVID-19 patients (26). Similarly, in another retrospective study, authors found arbidol as a superior therapeutic agent in the negative conversion of patients for SARS-CoV-2 nucleic acid and shorter duration of positive RNA test over lopinavir/ritonavir therapy (27). In addition, arbidol therapy was also found to be efficient in the improvement of pneumonia-associated symptoms and chest imaging in another retrospective study $(n=4)$ while it was given in combination with some other antiviral and Chinese medicine (28) (Table 2).

\section{Favipiravir}

Favipiravir is an investigational generic prodrug licensed for the treatment of influenza in Japan and also suggested for the treatment of the Ebola virus infection along with other viral infections (29-32). It is metabolized into its active form, favipiravir-ribofuranosyl-5'-triphosphate, and inhibits viral replication by inhibiting RNA-dependent RNA polymerase (RdRp) needed for viral transcription in host cells (33). As RdRp-mediated transcription is an important mechanism of SARS-CoV-2 replication in human body cells, favipiravir is assumed to have potential therapeutic efficiency in the treatment of COVID-19 patients.

To evaluate its efficiency in the treatment of COVID-19 patients, Cai et al. conducted an open-label nonrandomized control study and found a shorter median time (4 days) of viral clearance among patients treated with favipiravir than the median time of 11 days in those who received 
Table 2 Clinical trials of arbidol

\begin{tabular}{|c|c|c|c|c|c|}
\hline Authors & Year & Country & Study type & No. of participants & Findings \\
\hline Wang et al. & 2020 & China & $\begin{array}{l}\text { Retrospective cohort } \\
\text { study }\end{array}$ & $\begin{array}{l}\text { Total }=69 ; \text { arbidol treatment } \\
\text { group }=36 ; \text { arbidol untreated } \\
\text { group }=33\end{array}$ & $\begin{array}{l}\text { Arbidol found to be associated with increased } \\
\text { discharging rate from hospital ( } 33 \% \text { vs. only } 19 \% \\
\text { in Arbidol untreated group) and decreased } \\
\text { mortality rate }\end{array}$ \\
\hline Zhu et al. & 2020 & China & $\begin{array}{l}\text { Retrospective cohort } \\
\text { study }\end{array}$ & $\begin{array}{l}\text { Total }=50 ; \text { arbidol treatment } \\
\text { group }=16 ; \text { lopinavir/ritonavir } \\
\text { treatment group }=34\end{array}$ & $\begin{array}{l}\text { On day } 14 \text { following hospitalization all patient in } \\
\text { Arbidol group found undetectable for viral load } \\
\text { while only } 44.1 \% \text { in lopinavir/ritonavir group found } \\
\text { undetectable for viral load }\end{array}$ \\
\hline
\end{tabular}

SARS-CoV-2, severe acute respiratory syndrome coronavirus 2.

Table 3 Clinical trials of favipiravir

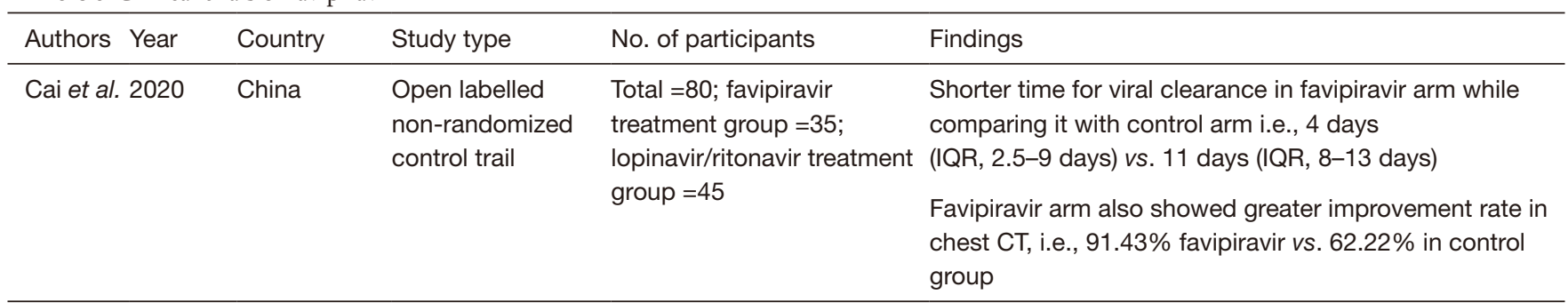

$I Q R$, interquartile range.

lopinavir/ritonavir. Favipiravir also was found superior in the improvement rate of chest imaging over the control group (91.43\% vs. 62.22\%). In the study, favipiravir showed to have greater efficiency in the treatment of COVID-19 with minimal adverse reactions (34). Due to its potential efficacy, it was approved for urgent and clinical trial use in the treatment of COVID-19 patients in China (35) (Table 3).

\section{Remdesivir}

Remdesivir (GS-5734) is a prodrug of 1'-cyano-substituted nucleotide analogue with broad spectrum antiviral activity against several RNA viruses by inhibiting viral replication through inhibiting RdRp (36,37). It was previously targeted for Ebola, SARS, and MERS and now has been accessed for its efficiency against COVID-19 (38,39). Many in vitro studies observed remdesivir to have a potent inhibiting effect against
SARS-CoV-2 $(14,40,41)$. Apart from its efficiency to inhibit SARS-CoV-2 in different in vitro studies, in a randomized, double-blind, placebo-controlled multicenter study with 237 COVID-19 patients, authors found a 2-day benefit with regard to time to clinical improvement in the remdesivir group over the placebo group with similar mortality in both groups. In this study, remdesivir seemed to have no difference but numerically associated with a rapid improvement of the clinical conditions of COVID-19 patients, while remdesivir was terminated early because of adverse events in more patients than the placebo (42). Supplementary to the above-mentioned studies, another most recently published double-blind, randomized, placebo-controlled trial also supported the efficacy and safety of remdesivir in the treatment of COVID-19. The study found remdesivir to be associated with a median of a 4 -day shorter recovery time and $4.8 \%$ less mortality rate than the placebo (43). The inconsistent results 
Table 4 Clinical trials of remdesivir

\begin{tabular}{|c|c|c|c|c|c|}
\hline Author & Year & Country & Study type & No. of participants & Findings \\
\hline Beigel et al. & 2020 & Multiple & $\begin{array}{l}\text { Double blind } \\
\text { randomized } \\
\text { placebo-controlled } \\
\text { trail }\end{array}$ & $\begin{array}{l}\text { Total }=1,062 ; \\
\text { remdesivir treatment } \\
\text { group }=541 ; \\
\text { placebo }=521\end{array}$ & $\begin{array}{l}\text { Faster recovery time was seen in remdesivir } \\
\text { treatment group as compared with placebo } \\
\text { (median of } 10 \text { vs. } 15 \text { days) } \\
15^{\text {th }} \text { and } 29^{\text {th }} \text { day mortality rates were found to be } \\
\text { less in remdesivir treatment group as compared } \\
\text { with placebo, i.e., } 6.7 \% \text { vs. } 11.9 \% \text { and } 11.4 \% \text { vs. } \\
15.2 \% \text { respectively } \\
\text { Serious adverse event also found to be less in } \\
\text { remdesivir group. i.e., } 24.6 \% \text { in remdesivir } \\
\text { treatment group vs. } 31.6 \% \text { in placebo }\end{array}$ \\
\hline Grein et al. & 2020 & Multiple & $\begin{array}{l}\text { Retrospective } \\
\text { cohort study }\end{array}$ & Total $=53$ & $\begin{array}{l}\text { At median follow up of } 18 \text { days } 68 \% \text { COVID- } 19 \\
\text { patients had improvement in oxygen support with } \\
\text { only } 13 \% \text { mortality rate }\end{array}$ \\
\hline Holshue et al. & 2020 & USA & Case report & Total $=1$ & $\begin{array}{l}\text { Good clinical improvement which leads to } \\
\text { discontinuation of oxygen supplementation }\end{array}$ \\
\hline
\end{tabular}

COVID-19, coronavirus disease 2019.

might be due to the different severity of the enrolled patients, who were much more severe in the former study. In another study, researchers found overall clinical improvement and oxygenation in a total of $68 \%$ patients who received remdesivir on compassionate use basis (44). In a case report of the first COVID-19 patient in the USA, remdesivir was found to be associated with good clinical improvement along with the discontinuation of oxygen supplementation (45). Recently, the Food and Drug Administration had authorized the emergency use of remdesivir in the treatment of COVID-19 (46). Now, hundreds of COVID-19 patients in the USA and Europe are receiving remdesivir as an antiviral therapy but due to the uncertain efficiency and safety, remdesivir needs to be explored with larger sample-sized, randomized, controlled clinical trials (Table 4).

\section{Cbloroquine (CQ) and bydroxychloroquine (HCQ)}

CQ and HCQ are easily accessible and cheaper drugs approved for the treatment of malaria for more than 70 years. They are also known for their immunomodulatory property as well as their broad-spectrum antiviral activity. The antiviral activity was found to be achieved through the increment of lysosomal PH leading to the inhibition of endocytic cell entry of viruses $(47,48)$ along with the alteration of the glycosylation process of angiotensin converting enzyme 2 (ACE2) receptor preventing viral fusion with host cells in both the pre- and post-infection situations (49). Many in vitro studies showed their (CQ and HCQ) effectiveness in viral inhibition against SARS-CoV-2 with a superior safety profile for HCQ than CQ $(41,50,51)$.

Besides in vitro studies, Chen et al. conducted a randomized control trial to explore the efficacy of HCQ therapy in COVID-19 treatment. Researchers found that $80.6 \%$ of patients in the treatment group showed improvement in pneumonia while only $54.8 \%$ of patients in the control group showed such improvement. The study gave the impression that HCQ had great potency for the reduction in duration of clinical improvement as well as pneumonia (52). Additionally, in a small sample-sized ( $\mathrm{n}=36$ ) open-label, non-randomized clinical trial, researchers observed HCQ as the most potent agent 
for positive to negative conversion of SARS-CoV-2 nucleic acid in COVID-19 patients when its effect was increased by the co-administration of azithromycin (53). The antiviral activity of azithromycin against SARS-COV-2 is hypothesized to be attributed to its interaction with CD147. CD147 is recognized as a receptor along with ACE2 receptor used by SARS-COV-2 to infect host cells (54). Azithromycin was also found to exert a synergistic effect in combination with HCQ in an in vitro study (55). Furthermore, it is found as a potential candidate against SARS-COV-2 in a bioinformatics analysis due to its ability to exert its antiviral effects via autophagy. However, another small sample-sized prospective study reported no strong antiviral activity of HCQ with azithromycin in terms of clinical improvement (56). In another small sample-sized retrospective study, authors also found no association in reduction of risk of mechanical ventilation or overall mortality (57). In addition, a separate cohort study also did not find any significant reduction in intensive care unit admission or the development of acute respiratory distress syndrome along with hypoxemic pneumonia in hospitalized COVID-19 patients who received HCQ (58). Furthermore, a pilot prospective study also reported that there was no improvement in the virus clearance rate, time to clinical improvement, and radiological progression in COVID-19 patients, when compared with those who received only conventional therapy (59). Moreover, in a separate observational study, HCQ seemed to have no association to either increased or reduced risk of intubation or death (60). In another open-label, randomized control trial, authors observed a good rate of negative conversion of viruses among those with mild to moderate disease, but HCQ therapy had no significantly higher probability of negative conversion over standard therapy (61) (Table 5).

\section{Ribavirin}

Ribavirin is another broad-spectrum nucleoside analogue antiviral drug, previously approved for the management of infections caused by respiratory syncytial viruses and hepatitis $C$ virus $(62,63)$. It was extensively used during the SARS outbreak in Hongkong but the therapy had faced much criticism on its efficacy and safety in the treatment of SARS (64). However, a study supported its efficiency in inhibiting SARS-CoV replication in various animal cells as well as humans inoculated with a strain of SARS-CoV $(65,66)$. However, its efficacy against
SARS-CoV-2 is uncertain until present, and a clinical trial (reg no. NCT04276688) is under way to explore its efficacy and safety profile against SARS-CoV-2 in the treatment of COVID-19.

\section{Oseltamivir}

Oseltamivir is a neuraminidase inhibitor and a prodrug of oseltamivir carboxylate with superior inhibiting effect against Influenza A and Influenza B infections (67). However, no study was published on database showing its efficacy against COVID-19 despite of one silico identification study to explore its efficacy against COVID-19 which stated that oseltamivir had a potent inhibitory effect on the protease of SARS-CoV-2 (68). In addition, it was reported for its administration in China during the COVID-19 epidemic along with other molecule like antibiotics or glucocorticoids (69). To prove its efficacy and safety against COVID-19, several trials are ongoing, along with other therapeutic molecules under reg no. NCT04303299, NCT04338698, NCT04255017, NCT04261270 and NCT04371601.

\section{Ivermectin}

Ivermectin (ivermectin is a semisynthetic derivative of avermectin B1) is a broad-spectrum and well-tolerated anti-parasitic agent and presently approved for the treatment of onchocerciasis, lymphatic filariasis, strongyloidiasis and/or scabies (70). Its antiviral activity was tested by Australian researchers in an in vitro study through infecting a Vero/hSLAM cell with clinically isolated SARS-CoV-2 strain Australia/VIC01/2020 and they found ivermectin as an intense potent agent for the inhibition of SARS-CoV-2 (71). We found 18 ongoing clinical trials to explore its efficacy and safety in the treatment of COVID-19, some of which are in phase III (72).

\section{Nitazoxanide}

Nitazoxanide is a broad-spectrum anti-helminthic drug with broad-spectrum antiviral activity. It is indicated for the treatment of cryptosporidiosis, giardiasis, and influenza and have shown a potent antiviral effect against MERS-CoV in an in vitro study (73,74). Most recently, the drug is also found to have a potent inhibitory effect against SARS-CoV-2 in a separate in vitro study which warranted further exploration in the treatment of COVID-19 (41). 
Table 5 Clinical trials of chloroquine and hydroxychloroquine

\begin{tabular}{|c|c|c|c|c|c|}
\hline Author & year & country & Study type & No. of participants & Findings \\
\hline Magagnoli et al & .2020 & USA & $\begin{array}{l}\text { Retrospective } \\
\text { cohort study }\end{array}$ & $\begin{array}{l}\text { Total =368; } \mathrm{HCQ} \\
\text { treatment group =97; } \\
\mathrm{HCQ}+\mathrm{AZ} \text { treatment } \\
\text { group =113; control } \\
=158\end{array}$ & $\begin{array}{l}\text { Mortality rate was significantly higher in } \mathrm{HCQ} \text { alone treatment } \\
\text { group as compared to } \mathrm{HCQ}+\mathrm{AZ} \text { and control group, i.e., } 27.8 \% \\
\text { vs. } 22.1 \% \text { vs. } 11.4 \% \text { respectively. } \\
\text { The risk of mechanical ventilation was lower in } \mathrm{HCQ}+\mathrm{AZ} \\
\text { treatment group as compared with } \mathrm{HCQ} \text { and control group which } \\
\text { was } 6.9 \% \text { vs. } 13.3 \% \text { vs. } 14.1 \% \text { respectively }\end{array}$ \\
\hline Mahevas et al. & 2020 & France & $\begin{array}{l}\text { Retrospective } \\
\text { analysis }\end{array}$ & $\begin{array}{l}\text { Total }=181 ; \mathrm{HCQ} \\
\text { treatment group }=84 ; \\
\text { no } \mathrm{HCQ} \text { treatment } \\
\text { group }=97\end{array}$ & $\begin{array}{l}\text { Within } 7 \text { day } 22.1 \% \text { patients in no HCQ treatment group were } \\
\text { transferred to ICU or died } 20.1 \% \text { in HCQ group showed such } \\
\text { event }\end{array}$ \\
\hline Geleris et al. & 2020 & USA & Observational & $\begin{array}{l}\text { Total }=1,376 ; \mathrm{HCQ} \\
\text { treatment group }=811 ; \\
\text { no } \mathrm{HCQ} \text { treatment } \\
\text { group }=565\end{array}$ & $\begin{array}{l}\text { With HR } 1.04 \text { \& } 95 \% \mathrm{Cl}: 0.82-1.32 \text { there was no significant } \\
\text { association of } \mathrm{HCQ} \text { treatment to deaths in COVID-19 patients }\end{array}$ \\
\hline Tang et al. & 2020 & China & $\begin{array}{l}\text { Open labelled } \\
\text { randomized } \\
\text { control trail }\end{array}$ & $\begin{array}{l}\text { Total }=150 ; \mathrm{HCQ} \\
\text { treatment group }=75 ; \\
\text { standard treatment } \\
\text { group }=75\end{array}$ & $\begin{array}{l}\text { With } 85.4 \% \text { viral negative conversion rate } \mathrm{HCQ} \text { treatment group } \\
\text { found to have } 4.1 \% \text { superior negative conversion rate than } \\
\text { standard treatment group, i.e., } 81.3 \% \\
\text { The median time for viral negative conversion was almost similar } \\
\text { in both treatment groups ( } 8 \text { days in } \mathrm{HCQ} \text { vs. } 7 \text { days in standard } \\
\text { treatment group) }\end{array}$ \\
\hline
\end{tabular}

$\mathrm{HCQ}$, hydroxychloroquine; AZ, azithromycin; SARS-CoV-2, severe acute respiratory syndrome coronavirus 2 . 


\section{Monoclonal antibody (tocilizumab)}

Pathogen-associated molecular pattern and damageassociated molecular pattern trigger the production of IL-6 from immune cells, mesenchymal cells, epithelial cells, and fibroblasts. IL-6 triggers acute phase immune response and is involved in the pathogenesis of several autoimmune diseases including cytokine release syndrome (CRS). In a retrospective study, researchers found a high level of IL-6, IL-1, and other cytokines in severe COVID-19 cases (75). As severe COVID-19 cases showed a cytokine pattern similar to CRS, tocilizumab has been hypothesized for treating severe COVID-19. Tocilizumab is a humanized monoclonal antibody and approved for the treatment of rheumatoid arthritis and several other autoimmune diseases. It is directed towards IL-6 receptor and controls effects of over production of IL-6 (76). Although it has no direct antiviral effects, it exerts its antiviral potential as adjunct therapy through the inhibition of proinflammatory responses mediated by viruses (77). Its potential therapeutic effect in COVID-19 is being tested in several clinical trials.

A rapid resolution of clinical symptoms, normalization of all inflammatory markers, improvement of oxygenation, and negative conversion of SARS-CoV-2 nucleic acid in COVID-19 patients was observed following administration of tocilizumab in various small sample-sized studies (78-81). For further exploration of its efficacy and safety, clinical trials with reg no. ChiCTR2000030196, ChiCTR2000030442, and ChiCTR2000029765 are already on their way in different phases of progression. Nonetheless, tocilizumab is also recommended by the National Health and Family Planning Commission of China for the treatment of seriously ill COVID-19 patients (82).

In addition to the above-mentioned role of IL- 6 in the pathogenesis of severe COVID-19 including its approach in blocking its production and managing COVID-19 cases, there is another alternative way towards the management of severe COVID-19 sharing similar manifestations with CRS. As IL-1 causes induction of IL-6 response and other cytokines, IL-1 also mediates the initiation of cytokine pattern similar to that of CRS and macrophage activation syndrome in severe COVID-19 patients (83). Thus, it was hypothesized that early blocking of IL-1 production with IL-1 receptor antagonist anakinra can significantly reduce the activity of proinflammatory cytokines including IL-6. Anakinra was previously approved for the treatment of several autoinflammatory disorders including macrophage activation syndrome. In a retrospective cohort study, authors found that $72 \%$ of patients who were treated with high dose anakinra showed a significant reduction in the level of C-reactive protein and a good respiratory improvement with 21 days survival of about $90 \%$ (84). A similar result was found in another retrospective study, which showed all patients who received anakinra as treatment improved clinically without any mortality (85).

\section{Convalescent plasma therapy}

In the absence of definitive therapeutic agent and vaccine, a passive immunotherapy like convalescent plasma therapy, which were previously fruitfully engaged in the treatment of SARS, MERS, and influenza, is deemed to be efficiently beneficial for the treatment of severely ill COVID-19 patients during the first week of the disease when viremia is thought to be at its peak. Convalescent plasma contains neutralizing antibodies which prevent virus cell penetration, as well as induction of phagocytosis for the clearance of viral structure and activate natural killer cells to eliminate infected cells (86-89).

A prospective cohort study on 10 seriously ill COVID-19 patients showed rapid improvement of clinical symptoms and oxygenation along with chest radiography in the majority of patients following administration of convalescent plasma containing neutralizing antibodies against SARS-CoV-2. The researches transfused $200 \mathrm{~mL}$ of convalescent plasma containing neutralizing antibody titer of $>1: 640$ and found a rapid increment in the level of neutralizing antibody titer in five patients while other five maintained a high titer of $>1: 640$ (90). In addition to the above study, there were several independent case reports which also supported the excellent recovery from COVID-19 symptoms along with the negative conversion of SARS-CoV-2 nucleic acid following administration of convalescent plasma. In a preliminary uncontrolled case series, authors found rapid normalization of body temperature along with the improvement of ARDS and decreased oxygen demand following transfusion of convalescent plasma containing neutralizing antibody titer of $>1: 1,000(91,92)$. A similar result on the reduction of oxygen requirement and an improved survival rate following transfusion of convalescent plasma containing neutralizing antibody $>1: 320$ was described in another retrospective study (93). In a recent randomized control trial, authors have not found a significant difference in the $28^{\text {th }}$ day of clinical improvement as well as mortality and discharge from hospital 
Table 6 Clinical trials of convalescent plasma therapy

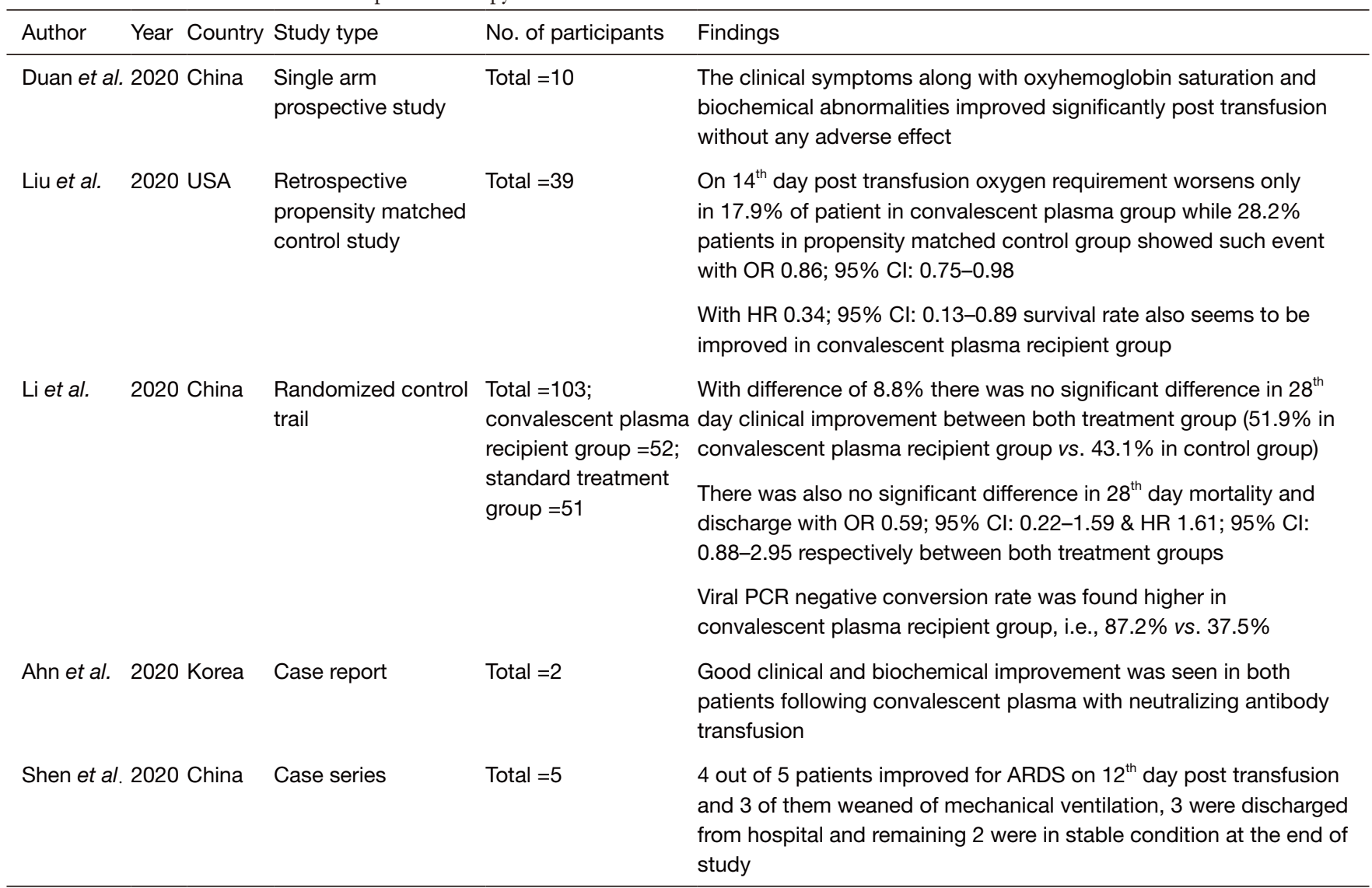

OR, odds ratio; $\mathrm{HR}$, hazard ratio; $\mathrm{Cl}$, confidence interval; ARDS, acute respiratory distress syndrome.

among those who received convalescent plasma transfusion with $\mathrm{S}$ protein receptor-binding domain (s-RBD) specific IgG titer $>1: 640$ from patients who received only standard therapies (94). Convalescent plasma therapy has also received clinical permission for its emergency use and investigational administration in seriously ill COVID-19 patients from the Food and Drug Administration of the United States (95) (Table 6).

\section{Interferon}

The antiviral properties of interferon have been explored during viral interference studies. Several stimuli such as viral infection triggers human interferon system to synthesize interferon and establish an antiviral state. There are two types of interferons, namely type 1 or viral interferons and type 2 or immune interferons. Type 1 interferons include IFN- $\alpha$, IFN- $\beta$, and IFN- $\omega$. Type 2 interferon includes IFN- $\gamma$. Viral infections induce the production of type 1 interferons. Interferons induce the synthesis of direct antiviral effector molecules like RNA dependent protein kinase, 2',5'-oligodenylate synthetase, and Mx protein GTPases to exert their antiviral effects (96). Interferon response occurs earlier than immune response to provide an early host defense. Interferon is an immune enhancer used in several observational studies for its effectiveness against SARS-CoV and MERS$\mathrm{CoV}(97,98)$. When combined with other approved antiviral drugs, it was found to be a total inhibitor of cytopathic effects of SARS-CoV in vitro (99). Although it proved its effectiveness against SARS-CoV and MERS-CoV, several clinical trials are ongoing to prove its efficacy against SARS-CoV-2 with favipiravir under clinical trial reg no. chiCTR2000029600 and with ribavirin under reg no. chiCTR2000029387.

\section{fanus kinase inhibitor (baricitinib)}

Janus kinase is an intercellular signaling pathway responsible for the production of various cytokines in the manifestation 
of viral infections $(100,101)$. Janus kinase inhibitors like baricitinib presently are approved drugs for the treatment of rheumatoid arthritis (102). Baricitinib exerts its antiviral effect by inhibiting AP2-associated protein kinase which is needed for entrance of SARS-CoV-2 into host cells as well as inhibition of abnormal production of cytokines like IL-6 (103). Due to its hypothetical potency, it was suggested for trial in appropriate human populations $(104,105)$.

\section{Miscellaneous}

Besides the above-discussed antiviral agents, several other antiviral agents like zanamivir, darunavir, galidesivir, peptide like EK1, and camostat mesylate might be effective in the treatment of COVID-19 but these need further exploration.

\section{Conclusions}

At present, we are facing SARS-COV-2 which emerged as a despicable virus with high infectivity. Currently, there is no specific molecule or drug regimens specified for the treatment of COVID-19. Many drugs or molecules which showed their potency in vitro or hypothesized to be effective against SARS-COV-2 are being clinically tested for their safety and efficacy. Remdesivir seems to have a potential antiviral activity against SARS-COV-2. Additionally, favipiravir and arbidol, along with a combination of azithromycin and HCQ, also seem to have acceptable potency as alternate antiviral treatments for COVID-19. Nonetheless, some biologics including tocilizumab, anakinra, interferons, and convalescent plasma therapy containing neutralizing antibody are also found to be potential agents for the treatment of severe COVID-19 cases complicated by an abnormal cytokine pattern. Constantly evolving new evidences, exclusive adult data, language barrier, and type of study (observational, retrospective, small-sized clinical trials, or independent case series) resulted to some limitations in this review. We feel the need for a multicentered, large sample-sized, randomized, placebo-controlled trial on appropriate COVID-19 patients to reach a proper conclusion on the most promising antiviral agent.

\section{Acknowledgments}

Funding: This study was supported by the National Natural Science Foundation of China (No. 82070102 and 81770097), the Project of Science and Technology
Commission of Shanghai Municipality (No. 20ZR1451500 and 17411970800), the Fund of Shanghai Youth Talent Support Program, the Fund of Shanghai Municipal Health Commission for Excellent Young Scholars (No. 2018YQ01), and the Shanghai Sailing Program (No. 19YF1444100).

\section{Footnote}

Reporting Checklist: The authors have completed the Narrative Review reporting checklist. Available at http:// dx.doi.org/10.21037/apm-20-1755

Peer Review File: Available at http://dx.doi.org/10.21037/ apm-20-1755

Conflicts of Interest: All authors have completed the ICMJE uniform disclosure form (available at http://dx.doi. org/10.21037/apm-20-1755). The authors have no conflicts of interest to declare.

Ethical Statement: The authors are accountable for all aspects of the work in ensuring that questions related to the accuracy or integrity of any part of the work are appropriately investigated and resolved.

Open Access Statement: This is an Open Access article distributed in accordance with the Creative Commons Attribution-NonCommercial-NoDerivs 4.0 International License (CC BY-NC-ND 4.0), which permits the non-commercial replication and distribution of the article with the strict proviso that no changes or edits are made and the original work is properly cited (including links to both the formal publication through the relevant DOI and the license). See: https://creativecommons.org/licenses/by-nc-nd/4.0/.

\section{References}

1. Yan Y, Shin WI, Pang YX, et al. The first 75 Days of novel coronavirus (SARS-CoV-2) outbreak: recent advances, prevention, and treatment. Int J Environ Res Public Health 2020;17:2323.

2. Zaki AM, van Boheemen S, Bestebroer TM, et al. Isolation of a novel coronavirus from a man with pneumonia in Saudi Arabia. N Engl J Med 2012;367:1814-20.

3. Zhong NS, Zheng BJ, Li YM, et al. Epidemiology and cause of severe acute respiratory syndrome (SARS) in Guangdong, People's Republic of China, in February, 2003. Lancet 2003;362:1353-8. 
4. Zhu N, Zhang D, Wang W, et al. A Novel Coronavirus from Patients with Pneumonia in China, 2019. N Engl J Med 2020;382:727-33.

5. Liu Y, Gayle AA, Wilder-Smith A, et al. The reproductive number of COVID-19 is higher compared to SARS coronavirus. J Travel Med 2020;27:taaa021.

6. Guan WJ, Ni ZY, Hu Y, et al. Clinical Characteristics of Coronavirus Disease 2019 in China. N Engl J Med 2020;382:1708-20.

7. WHO. WHO Director-General's opening remarks at the media briefing on COVID-19 - 11 March 2020. 2020. Available online: https://www.who.int/dg/speeches/detail/

8. Korea Centers for Disease Control and Prevention (KCDC) Status of COVID-19 in Korea. 2020. Accessed 4th November 2020. Available online: http://ncov.mohw. go.kr/bdBoardList_Real.do?brdId=1\&brdGubun=11\&ncv ContSeq=\&contSeq=\&board_id=\&gubun=

9. Surveillances V. The epidemiological characteristics of an outbreak of 2019 novel coronavirus diseases (COVID-19)_China, 2020. China CDC Weekly 2020;2:113-22.

10. Istituto Superiore di Sanità Epidemia COVID-19. 2020. Accessed 4th November 2020. Available online: https:// www.epicentro.iss.it/coronavirus/bollettino/Bollettinosorveglianza-integrata-COVID-19_2-aprile-2020.pdf

11. Huang J, Zhu L, Bai X, et al. Multidimensional Analysis of Risk Factors for the Severity and Mortality of Patients with COVID-19 and Diabetes. Infect Dis Ther 2020;9:981-1002.

12. Wu CY, Jan JT, Ma SH, et al. Small molecules targeting severe acute respiratory syndrome human coronavirus. Proc Natl Acad Sci U S A 2004;101:10012-7.

13. Mukherjee P, Desai P, Ross L, et al. Structure-based virtual screening against SARS-3CL(pro) to identify novel non-peptidic hits. Bioorg Med Chem 2008;16:4138-49.

14. Pruijssers AJ, George AS, Schäfer A, et al. Remdesivir Inhibits SARS-CoV-2 in Human Lung Cells and Chimeric SARS-CoV Expressing the SARS-CoV-2 RNA Polymerase in Mice. Cell Rep 2020;32:107940.

15. Lan X, Shao C, Zeng X, et al. Lopinavir-ritonavir alone or combined with arbidol in the treatment of 73 hospitalized patients with COVID-19: a pilot retrospective study. medRxiv 2020. doi: https://doi.org/10.1101/2020.04.25.20 079079.

16. Cao B, Wang Y, Wen D, et al. A Trial of Lopinavir-Ritonavir in Adults Hospitalized with Severe Covid-19. N Engl J Med 2020;382:1787-99.

17. Zhou F, Yu T, Du R, et al. Clinical course and risk factors for mortality of adult inpatients with COVID-19 in Wuhan, China: a retrospective cohort study. Lancet 2020;395:1054-62.

18. Ye XT, Luo Y, Xia S, et al. Clinical efficacy of lopinavir/ ritonavir in the treatment of Coronavirus disease 2019. Eur Rev Med Pharmacol Sci 2020;24:3390-6.

19. Lim J, Jeon S, Shin HY, et al. Case of the Index Patient Who Caused Tertiary Transmission of COVID-19 Infection in Korea: the Application of Lopinavir/Ritonavir for the Treatment of COVID-19 Infected Pneumonia Monitored by Quantitative RT-PCR. J Korean Med Sci 2020;35:e79.

20. Tang B, Li S, Xiong Y, et al. COVID-19 Pneumonia in a Hemodialysis Patient. Kidney Med 2020;2:354-8.

21. Young BE, Ong SWX, Kalimuddin S, et al. Epidemiologic Features and Clinical Course of Patients Infected With SARS-CoV-2 in Singapore. JAMA 2020;323:1488-94.

22. Blaising J, Polyak SJ, Pécheur E-I. Arbidol as a broadspectrum antiviral: An update. Antiviral Res 2014;107:84-94.

23. Leneva IA, Russell RJ, Boriskin YS, et al. Characteristics of arbidol-resistant mutants of influenza virus: implications for the mechanism of anti-influenza action of arbidol. Antiviral Res 2009;81:132-40.

24. Boriskin YS, Pécheur EI, Polyak SJ. Arbidol: a broadspectrum antiviral that inhibits acute and chronic HCV infection. Virol J 2006;3:56.

25. Li Y, Xie Z, Lin W, et al. Efficacy and Safety of Lopinavir/ Ritonavir or Arbidol in Adult Patients with Mild/Moderate COVID-19: An Exploratory Randomized Controlled Trial. Med (N Y) 2020;1:105-13.e4.

26. Wang Z, Yang B, Li Q, et al. Clinical Features of 69 Cases With Coronavirus Disease 2019 in Wuhan, China. Clin Infect Dis 2020;71:769-77.

27. Zhu Z, Lu Z, Xu T, et al. Arbidol monotherapy is superior to lopinavir/ritonavir in treating COVID-19. J Infect 2020;81:e21-3.

28. Wang Z, Chen X, Lu Y, et al. Clinical characteristics and therapeutic procedure for four cases with 2019 novel coronavirus pneumonia receiving combined Chinese and Western medicine treatment. Biosci Trends 2020;14:64-8.

29. Furuta Y, Gowen BB, Takahashi K, et al. Favipiravir (T-705), a novel viral RNA polymerase inhibitor. Antiviral Res 2013;100:446-54.

30. Goldhill DH, Te Velthuis AJW, Fletcher RA, et al. The mechanism of resistance to favipiravir in influenza. Proc Natl Acad Sci U S A 2018;115:11613-8.

31. Cardile AP, Warren TK, Martins KA, et al. Will There 
Be a Cure for Ebola? Annu Rev Pharmacol Toxicol 2017;57:329-48.

32. Furuta Y, Komeno T, Nakamura T. Favipiravir (T-705), a broad spectrum inhibitor of viral RNA polymerase. Proc Jpn Acad Ser B Phys Biol Sci 2017;93:449-63.

33. Tanaka T, Kamiyama T, Daikoku T, et al. T-705 (Favipiravir) suppresses tumor necrosis factor $\alpha$ production in response to influenza virus infection: A beneficial feature of T-705 as an anti-influenza drug. Acta Virol 2017;61:48-55.

34. Cai Q, Yang M, Liu D, et al. Experimental Treatment with Favipiravir for COVID-19: An Open-Label Control Study. Engineering (Beijing) 2020;6:1192-8.

35. daily.com.in c. Potential coronavirus drug approved for marketing. 2020. Available online: https://www.chinadaily. com.cn/a/202002/17/WS5e49efc2a310128217277fa3.html

36. Siegel D, Hui HC, Doerffler E, et al. Discovery and Synthesis of a Phosphoramidate Prodrug of a Pyrrolo[2,1-f][triazin-4-amino] Adenine C-Nucleoside (GS-5734) for the Treatment of Ebola and Emerging Viruses. J Med Chem 2017;60:1648-61.

37. Gordon CJ, Tchesnokov EP, Feng JY, et al. The antiviral compound remdesivir potently inhibits RNA-dependent RNA polymerase from Middle East respiratory syndrome coronavirus. J Biol Chem 2020;295:4773-9.

38. Sheahan TP, Sims AC, Leist SR, et al. Comparative therapeutic efficacy of remdesivir and combination lopinavir, ritonavir, and interferon beta against MERS-CoV. Nat Commun 2020;11:222.

39. Paules CI, Marston HD, Fauci AS. Coronavirus infections-more than just the common cold. JAMA 2020;323:707-8.

40. Gordon CJ, Tchesnokov EP, Woolner E, et al. Remdesivir is a direct-acting antiviral that inhibits RNA-dependent RNA polymerase from severe acute respiratory syndrome coronavirus 2 with high potency. J Biol Chem 2020;295:6785-97.

41. Wang M, Cao R, Zhang L, et al. Remdesivir and chloroquine effectively inhibit the recently emerged novel coronavirus (2019-nCoV) in vitro. Cell Res 2020;30:269-71.

42. Wang Y, Zhang D, Du G, et al. Remdesivir in adults with severe COVID-19: a randomised, double-blind, placebo-controlled, multicentre trial. Lancet 2020;395:1569-78.

43. Beigel JH, Tomashek KM, Dodd LE. Remdesivir for the Treatment of Covid-19 - Preliminary Report. Reply. N Engl J Med 2020;383:994.
44. Grein J, Ohmagari N, Shin D, et al. Compassionate Use of Remdesivir for Patients with Severe Covid-19. N Engl J Med 2020;382:2327-36.

45. Holshue ML, DeBolt C, Lindquist S, et al. First Case of 2019 Novel Coronavirus in the United States. N Engl J Med 2020;382:929-36.

46. FDA. Coronavirus (COVID-19) Update: FDA Issues Emergency Use Authorization for Potential COVID-19 Treatment. 2020. Available online: https://www.fda.gov/ news-events/press-announcements/coronavirus-covid-19update-fda-issues-emergency-use-authorization-potentialcovid-19-treatment

47. Yan $Y, Z$ Zou Z, Sun Y, et al. Anti-malaria drug chloroquine is highly effective in treating avian influenza A H5N1 virus infection in an animal model. Cell Res 2013;23:300-2.

48. Savarino A, Di Trani L, Donatelli I, et al. New insights into the antiviral effects of chloroquine. Lancet Infect Dis 2006;6:67-9.

49. Vincent MJ, Bergeron E, Benjannet S, et al. Chloroquine is a potent inhibitor of SARS coronavirus infection and spread. Virol J 2005;2:69.

50. Liu J, Cao R, Xu M, et al. Hydroxychloroquine, a less toxic derivative of chloroquine, is effective in inhibiting SARS-CoV-2 infection in vitro. Cell Discov 2020;6:16.

51. Yao X, Ye F, Zhang M, et al. In Vitro Antiviral Activity and Projection of Optimized Dosing Design of Hydroxychloroquine for the Treatment of Severe Acute Respiratory Syndrome Coronavirus 2 (SARS-CoV-2). Clin Infect Dis 2020;71:732-9.

52. Chen $Z, \mathrm{Hu}$ J, Zhang $Z$, et al. Efficacy of hydroxychloroquine in patients with COVID-19: results of a randomized clinical trial. medRxiv 2020. doi: https://doi. org/10.1101/2020.03.22.20040758.

53. Gautret P, Lagier JC, Parola P, et al. Hydroxychloroquine and azithromycin as a treatment of COVID-19: results of an open-label non-randomized clinical trial. Int J Antimicrob Agents 2020;56:105949.

54. Ulrich H, Pillat MM. CD147 as a Target for COVID-19 Treatment: Suggested Effects of Azithromycin and Stem Cell Engagement. Stem Cell Rev Rep 2020;16:434-40.

55. Andreani J, Le Bideau M, Duflot I, et al. In vitro testing of combined hydroxychloroquine and azithromycin on SARS-CoV-2 shows synergistic effect. Microb Pathog 2020;145:104228.

56. Molina JM, Delaugerre C, Le Goff J, et al. No evidence of rapid antiviral clearance or clinical benefit with the combination of hydroxychloroquine and azithromycin in patients with severe COVID-19 infection. Med Mal Infect 
2020;50:384.

57. Magagnoli J, Narendran S, Pereira F, et al. Outcomes of hydroxychloroquine usage in United States veterans hospitalized with Covid-19. Preprint. medRxiv 2020;2020.04.16.20065920.

58. Mahevas M, Tran VT, Roumier M, et al. No evidence of clinical efficacy of hydroxychloroquine in patients hospitalized for COVID-19 infection with oxygen requirement: results of a study using routinely collected data to emulate a target trial. medRxiv 2020. doi: https:// doi.org/10.1101/2020.04.10.20060699.

59. Chen J, Liu D, Liu L, et al. A pilot study of hydroxychloroquine in treatment of patients with moderate COVID-19. Zhejiang Da Xue Xue Bao Yi Xue Ban 2020;49:215-9.

60. Geleris J, Sun Y, Platt J, et al. Observational Study of Hydroxychloroquine in Hospitalized Patients with Covid-19. N Engl J Med 2020;382:2411-8.

61. Tang W, Cao Z, Han M, et al. Hydroxychloroquine in patients with mainly mild to moderate coronavirus disease 2019: open label, randomised controlled trial. BMJ 2020;369:m1849.

62. Shahani L, Ariza-Heredia EJ, Chemaly RF. Antiviral therapy for respiratory viral infections in immunocompromised patients. Expert Rev Anti Infect Ther 2017;15:401-15.

63. Gross AE, Bryson ML. Oral Ribavirin for the Treatment of Noninfluenza Respiratory Viral Infections: A Systematic Review. Ann Pharmacother 2015;49:1125-35.

64. Ksiazek TG, Erdman D, Goldsmith CS, et al. A novel coronavirus associated with severe acute respiratory syndrome. N Engl J Med 2003;348:1953-66.

65. Morgenstern B, Michaelis M, Baer PC, et al. Ribavirin and interferon-beta synergistically inhibit SARS-associated coronavirus replication in animal and human cell lines. Biochem Biophys Res Commun 2005;326:905-8.

66. Cyranoski D. Critics slam treatment for SARS as ineffective and perhaps dangerous. Nature 2003;423:4.

67. Gubareva LV, Kaiser L, Hayden FG. Influenza virus neuraminidase inhibitors. Lancet 2000;355:827-35.

68. Mamidala E, Davella R, Gurrapu S, et al. In silico identification of clinically approved medicines against the main protease of SARS-CoV-2, causative agent of covid-19. arXiv preprint arXiv:2004.12055.

69. Gu J, Han B, Wang J. COVID-19: Gastrointestinal Manifestations and Potential Fecal-Oral Transmission. Gastroenterology 2020;158:1518-9.

70. González Canga A, Sahagún Prieto AM, Diez Liébana MJ, et al. The pharmacokinetics and interactions of ivermectin in humans--a mini-review. AAPS J 2008;10:42-6.

71. Caly L, Druce JD, Catton MG, et al. The FDA-approved drug ivermectin inhibits the replication of SARS-CoV-2 in vitro. Antiviral Res 2020;178:104787.

72. clinicaltrial.gov. May 25, 2020. Available online: https:// clinicaltrials.gov/ct $2 /$ results? cond=covid \& term=ivermectin $\mathrm{e} \& \mathrm{cntry}=\&$ state $=\&$ city $=\&$ dist $=$

73. Rossignol JF. Nitazoxanide: A first-in-class broad-spectrum antiviral agent. Antiviral Res 2014;110:94-103.

74. Rossignol JF. Nitazoxanide, a new drug candidate for the treatment of Middle East respiratory syndrome coronavirus. J Infect Public Health 2016;9:227-30.

75. Qin C, Zhou L, Hu Z, et al. Dysregulation of Immune Response in Patients With Coronavirus 2019 (COVID-19) in Wuhan, China. Clin Infect Dis 2020;71:762-8.

76. Mehta P, McAuley DF, Brown M, et al. COVID-19: consider cytokine storm syndromes and immunosuppression. Lancet 2020;395:1033-4.

77. Sakkas LI. Spotlight on tocilizumab and its potential in the treatment of systemic sclerosis. Drug Des Devel Ther 2016;10:2723-8.

78. Luo P, Liu Y, Qiu L, et al. Tocilizumab treatment in COVID-19: A single center experience. J Med Virol 2020;92:814-8.

79. Sernicola A, Carnicelli G, Di Fraia M, et al. 'Toxic erythema' and eosinophilia associated with tocilizumab therapy in a COVID-19 patient. J Eur Acad Dermatol Venereol 2020;34:e368-70.

80. van Kraaij TDA, Mostard RL, Ramiro S, et al. Tocilizumab in Severe COVID-19 Pneumonia and Concomitant Cytokine Release Syndrome. Eur J Case Rep Intern Med 2020;7:001675.

81. Zhang Y, Xu JM. Medical diagnosis and treatment strategies for malignant tumors of the digestive system during the outbreak of COVID-19. Zhonghua Zhong Liu Za Zhi 2020;42:184-6.

82. Chinese Guidelines for COVID-19 Pneumonia Diagnosis and Treatment (7th edition). 2020. Available online: http:// kjfy.meetingchina.org/msite/news/show/cn/3337.html

83. Cavalli G, Dinarello CA. Anakinra Therapy for Non-cancer Inflammatory Diseases. Front Pharmacol 2018;9:1157.

84. Cavalli G, De Luca G, Campochiaro C, et al. Interleukin-1 blockade with high-dose anakinra in patients with COVID-19, acute respiratory distress syndrome, and hyperinflammation: a retrospective cohort study. Lancet Rheumatol 2020;2:e325-31. 
85. Cauchois R, Koubi M, Delarbre D, et al. Early IL-1 receptor blockade in severe inflammatory respiratory failure complicating COVID-19. Proc Natl Acad Sci U S A 2020;117:18951-3.

86. Mair-Jenkins J, Saavedra-Campos M, Baillie JK, et al. The effectiveness of convalescent plasma and hyperimmune immunoglobulin for the treatment of severe acute respiratory infections of viral etiology: a systematic review and exploratory meta-analysis. J Infect Dis 2015;211:80-90.

87. Cheng Y, Wong R, Soo YO, et al. Use of convalescent plasma therapy in SARS patients in Hong Kong. Eur J Clin Microbiol Infect Dis 2005;24:44-6.

88. Dodd RY. Emerging pathogens and their implications for the blood supply and transfusion transmitted infections. $\mathrm{Br}$ J Haematol 2012;159:135-42.

89. Huang C, Wang Y, Li X, et al. Clinical features of patients infected with 2019 novel coronavirus in Wuhan, China. Lancet 2020;395:497-506.

90. Duan K, Liu B, Li C, et al. Effectiveness of convalescent plasma therapy in severe COVID-19 patients. Proc Natl Acad Sci U S A 2020;117:9490-6.

91. Ahn JY, Sohn Y, Lee SH, et al. Use of Convalescent Plasma Therapy in Two COVID-19 Patients with Acute Respiratory Distress Syndrome in Korea. J Korean Med Sci 2020;35:e149.

92. Shen C, Wang Z, Zhao F, et al. Treatment of 5 Critically Ill Patients With COVID-19 With Convalescent Plasma. JAMA 2020;323:1582-9.

93. Liu STH, Lin HM, Baine I, et al. Convalescent plasma treatment of severe COVID-19: a propensity score-matched control study. Nat Med 2020;26:1708-13.

94. Li L, Zhang W, Hu Y, et al. Effect of Convalescent Plasma Therapy on Time to Clinical Improvement in Patients With Severe and Life-threatening COVID-19: A Randomized Clinical Trial. JAMA 2020;324:460-70.

95. USFDA. Recommendations for Investigational COVID-19 Convalescent Plasma. 2020. Available online: https://

Cite this article as: Yadav AK, Wen S, Xu X, Yu L. Antiviral treatment in COVID-19: which is the most promising? a narrative review. Ann Palliat Med 2021;10(1):707-720. doi: 10.21037/apm-20-1755 www.fda.gov/vaccines-blood-biologics/investigationalnew-drug-ind-or-device-exemption-ide-process-cber/ recommendations-investigational-covid-19-convalescentplasma

96. Samuel CE. Antiviral actions of interferons. Clin Microbiol Rev 2001;14:778-809.

97. Momattin H, Al-Ali AY, Al-TawfiqJA. A Systematic Review of therapeutic agents for the treatment of the Middle East Respiratory Syndrome Coronavirus (MERS-CoV). Travel Med Infect Dis 2019;30:9-18.

98. Momattin H, Mohammed K, Zumla A, et al. Therapeutic options for Middle East respiratory syndrome coronavirus (MERS-CoV)--possible lessons from a systematic review of SARS-CoV therapy. Int J Infect Dis 2013;17:e792-8.

99. Tan EL, Ooi EE, Lin CY, et al. Inhibition of SARS coronavirus infection in vitro with clinically approved antiviral drugs. Emerg Infect Dis 2004;10:581.

100. O'Shea JJ, Plenge R. JAK and STAT signaling molecules in immunoregulation and immune-mediated disease. Immunity 2012;36:542-50.

101.Zhang W, Zhao Y, Zhang F, et al. The use of antiinflammatory drugs in the treatment of people with severe coronavirus disease 2019 (COVID-19): The Perspectives of clinical immunologists from China. Clin Immunol 2020;214:108393.

102.Al-Salama ZT, Scott LJ. Baricitinib: a review in rheumatoid arthritis. Drugs 2018;78:761-72.

103. Kuchipudi SV. The Complex Role of STAT3 in Viral Infections. J Immunol Res 2015;2015:272359.

104. Richardson P, Griffin I, Tucker C, et al. Baricitinib as potential treatment for 2019-nCoV acute respiratory disease. Lancet 2020;395:e30-1.

105.Perricone C, Triggianese P, Bartoloni E, et al. The anti-viral facet of anti-rheumatic drugs: Lessons from COVID-19. J Autoimmun 2020;111:102468. 